Original paper

\title{
Ombitasvir/paritaprevir/ritonavir + dasabuvir + ribavirin in HCV genotype 1 infected patients who failed previous protease inhibitor therapy
}

Béla Hunyady ${ }^{1,2}$, Margit Abonyi ${ }^{3}$, Zsuzsanna Gerlei ${ }^{4}$, Judit Gervain ${ }^{5}$, Gábor Horváth ${ }^{6,7}$, Viktor Jancsik ${ }^{8}$, Gabriella Lengyel ${ }^{9}$, Erzsébet Makkai1 ${ }^{10}$, Alajos Pár2 ${ }^{2}$ Zoltán Péter ${ }^{9}$, Margit Pusztay ${ }^{6}$, Pál Ribiczey ${ }^{11}$, László Rókusz ${ }^{12}$, Christoph Sarrazin ${ }^{13,14}$, Ferenc Schneider ${ }^{15}$, Simone Susser ${ }^{13}$, Ferenc Szalay ${ }^{3}$, István Tornai ${ }^{16}$, Anna Tusnádi ${ }^{17}$, Eszter Újhelyi ${ }^{18}$, Klára Werling9 Mihály Makara ${ }^{19}$

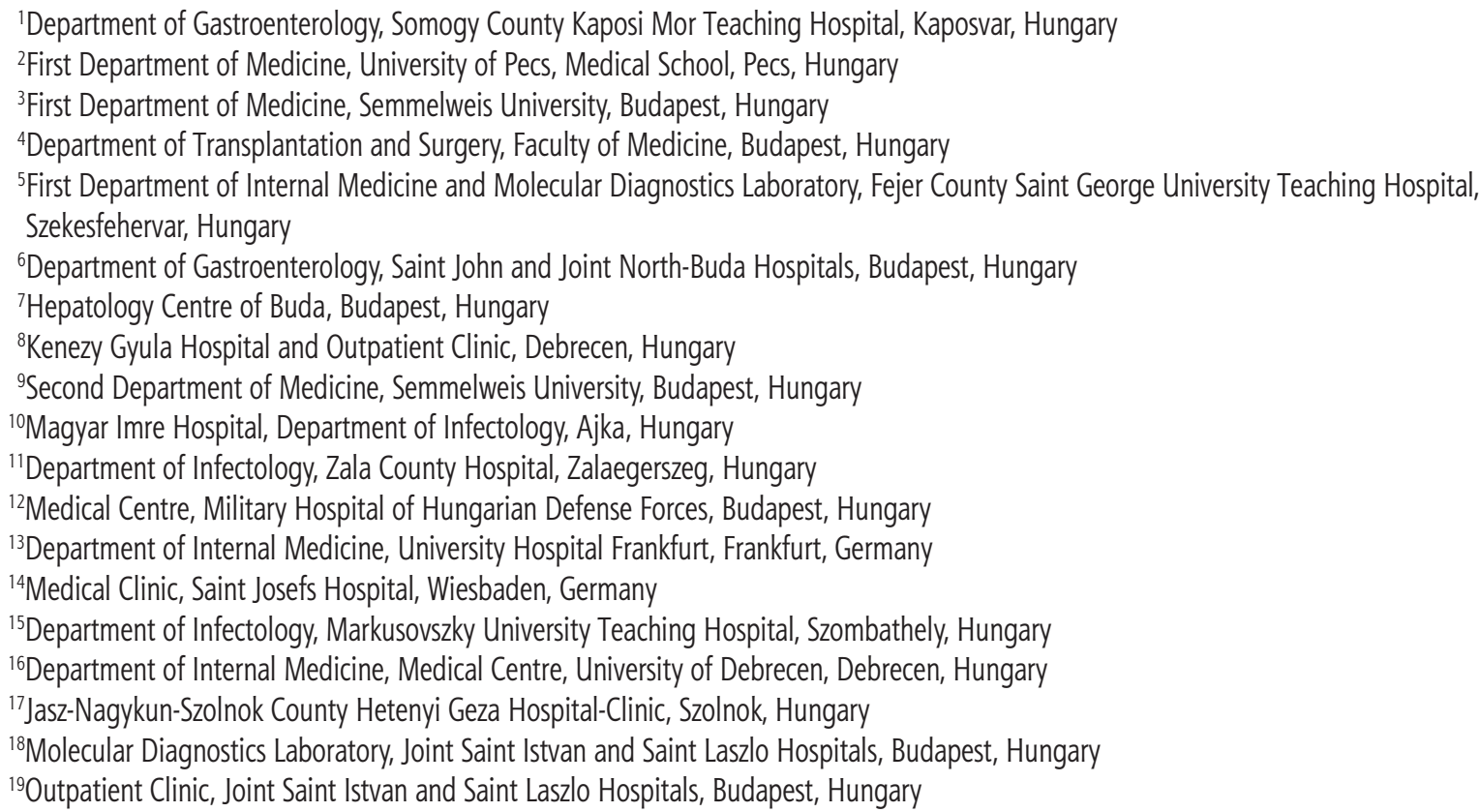

\begin{abstract}
Aim of the study: Combination of ombitasvir/paritaprevir/ritonavir + dasabuvir \pm ribavirin (3DDA $\pm R B V$ ) therapy is shown to be effective in HCV genotype 1 (GT1) infected patients. However, sparse data exist in patients who failed previous boceprevir or telaprevir based therapies. Real life efficacy and safety of this combination were evaluated in HCV GT1b infected patients (mostly cirrhotics) with compensated liver disease who failed previous boceprevir or telaprevir based therapies more than a year before.
\end{abstract}

Material and methods: Data of previous protease inhibitor failure patients, treated with 3DAA+RBV for 12 weeks (GT1b and/or non-cirrhotics) or 24 weeks (non-GT1b cirrhotics), were retrospectively collected.

Results: Population characteristics: boceprevir/telaprevirfailure: 82/45, GT1b: 117, cirrhotic: 111 (87.4\%). SVR12/24 was observed in 103/105 patients (98.1\%) of those who reached either time point. Four SAEs reported: one death due to myocardial infarction, another due to recurrent hepatocellular carcinoma after achieving SVR12, two hospitalizations (elevation of transaminases, pneumonia). Grade $\geqslant 3$ AEs or laboratory abnormalities were reported in $<10 \%$ of patients; they were transient in all patients. No early discontinuation of drugs due to SAE has been reported.

Conclusions: One year after previous failure of boceprevir or telaprevir based therapy, 12 weeks of 3DAA+RBV combination in HCV GT1b infected patients is similarly effective and safe as in those with no previous HCV ther- 
apy, even in the presence of cirrhosis. These findings might be of particular interest in settings where alternative therapies for such patients are not available or not affordable.

Key words: cirrhosis, direct acting antiviral drugs, hepatitis C virus, protease inhibitor.

\section{Address for correspondence}

Prof. Béla Hunyady, Somogy County Kaposi Mór Teaching Hospital, Tallián Gy. u. 20-32, 7400 Kaposvár, Hungary, phone: +36 82 501344, fax: +36 82 510076, e-mail: bhunyady@yahoo.com

\section{Introduction}

The first generation NS3/4A protease inhibitors (PIs) boceprevir (BOC) and telaprevir (TEL) were registered in 2011 for the treatment of HCV GT1 infection in triple combinations with pegylated interferon plus ribavirin (PegIFN+RBV) $[1,2]$. A common reason of failure of these PI-based therapies is development of resistance associated substitutions (RASs) [3-5]. To some extent, RASs are also present in most HCV infected patients even without previous antiviral therapy (baseline RASs) [4]. Cross-resistance between first generation PIs can potentially influence the efficacy of PI-containing direct acting antiviral drug (DAA) combinations after failure of a previous PI-based regimen. Using a population-based sequencing approach, long-term follow-up studies have shown the disappearance of RASs in a median time to loss of mutations in 9 months (TEL) to 1.04 years (BOC) in the majority of HCV GT1b infected patients.

Ombitasvir (HCV NS5A inhibitor), ritonavir (enzyme inhibitor) boosted paritaprevir (NS3A/4 protease inhibitor) and dasabuvir (non-nucleoside NS5B polymerase inhibitor) with or without addition of RBV (3DAA $\pm R B V)$ have been registered for the treatment of HCV GT1 or GT4 infected patients [6, 7]. However, the efficacy of $3 \mathrm{DAA} \pm \mathrm{RBV}$ therapy has not been evaluated during registration studies in patients who failed previous BOC or TEL containing triple therapies. Due to financial constraints, use of the 3DAA+RBV combination has been approved in the Hungarian HCV guideline for a subgroup of such patients with G1b infection [8].

Real life efficacy and safety of the 3DAA+RBV combination in HCV GT1b infected patients with compensated liver disease (mainly with cirrhosis), who failed previous BOC/TEL-based triple therapy more than a year before, were retrospectively analysed under the supervision of the Hungarian Hepatitis Therapeutics Committee, according to the decision of the physicians licensed to treat HCV in Hungary.

\section{Material and methods}

The decision on therapy was left entirely to the treating physicians and to the patients - however, there was no alternative reimbursed treatment option available in Hungary for this patient group. Treatments included 3DAA (per label) + RBV (600-1200 mg per day according to bodyweight, except patients with advanced kidney disease with lower doses) for 12 weeks (GT1b and all other non-cirrhotics) or 24 weeks (GT1 non- $1 \mathrm{~b}$ cirrhotics) according to the national guideline [8]. Non-GT1b patients were commenced on therapy before approval of the Hungarian guideline. Addition of RBV to the 3DAA combination in these GT1b infected patients was felt appropriate by consensus of the treating physicians in an attempt to maximize efficacy and minimize potential relapses.

Therapy-related data were either subtracted from the National Hepatitis Treatment Registry (baseline demographics, fibrosis stage by histology and/or transient elastography, type and outcome of previous therapy, $\mathrm{HCV}$ genotype/subtype, baseline/post-treatment $\mathrm{HCV}$ RNA, baseline ALT) for all consecutively treated patients or collected voluntarily from the treating physicians (co-morbidity, AE, SAE, haematology parameters by WHO class, GGT, treatment modification, discontinuation) in this retrospective cohort. Sustained virological response (SVR12/24) was defined as confirmed undetectable HCV RNS at post-treatment week 12 and/ or week 24 combined. Post-treatment week 12 PCR is not mandatory, and not routinely reimbursed in Hungary; however, it was made available for a proportion of patients from an unrestricted research grant. Not all of the included patients have reached post-treatment week 12 or 24 time points by the database lock. Intent to treat (ITT) analysis included all patients who initiated therapy, modified ITT (mITT) analysis those who completed the assigned 12 or 24 weeks therapy and were available for SVR12 and/or SVR24 assessment.

HCV RNA was assayed by either Abbott Real-Time or Roche COBAS AmpliPrep/TaqMan HCV v2.0 stan- 
dard methods with lower limits of HCV target detection (LLD) of 12 or $15 \mathrm{IU} / \mathrm{ml}$, respectively.

For patients with viral failure baseline RASs were retrospectively analysed from samples collected prior to therapy [9].

\section{Statistical methods}

Number and percentage of patients in different categories are reported, and descriptive statistical methods, including means or medians as well as standard error of the mean or range values, were used.

As pre-defined, members of the Hungarian Hepatitis Therapeutics Committee, and colleagues contributing with data of at least four patients or with RAS testing are listed as authors.

This was a retrospective, purely observational study with retrospective data collection. For this reason it is not registered in any clinical trial registries and no ethics committee review has been requested. However, the procedures followed were in accordance with the Helsinki Declaration of 1975, as revised in 1983.

\section{Results}

\section{Patient population}

Out of 127 patients enrolled, at the closure of data collection, SVR12 and/or SVR24 results were available for 104 patients. One patient was lost to follow-up prior to the end of treatment (included in the ITT analysis, but not included in the mITT analysis), while $22 \mathrm{pa}$ tients did not reach the EOT+24 week time point and have no available EOT+12 week HCV RNA result either (not routinely assessed in Hungary). These 22 patients are not included in the ITT/mITT SVR analyses.

Baseline characteristics of patients are shown in Table 1 . The majority of patients were cirrhotics $(87.4 \%)$

Table 1. Baseline characteristics of patients

\begin{tabular}{|c|c|c|c|}
\hline Parameter & Boceprevir & Telaprevir & Total \\
\hline Number of patients, $n$ & 82 & 45 & 127 \\
\hline Female/male, $n / n$ & $48 / 34$ & $22 / 23$ & $70 / 57$ \\
\hline Age, mean \pm SEM (range), years & $59.4 \pm 5.2(45-74)$ & $57.6 \pm 5.8(34-70)$ & $58.8 \pm 5.4(34-74)$ \\
\hline Body weight, mean \pm SEM (range), $\mathrm{kg}$ & $79.8 \pm 10.9(54-116)$ & $81.3 \pm 14.1(54-119)$ & $80.4 \pm 12.8(54-119)$ \\
\hline BMI, mean \pm SEM (range), $\mathrm{kg} / \mathrm{m}^{2}$ & $28.3 \pm 3.6(20.5-48.9)$ & $28.2 \pm 3.8(20.8-49.5)$ & $28.2 \pm 4.0(20.5-49.5)$ \\
\hline Liver stiffness, mean \pm SEM (range), kPa & $29.7 \pm 11.0(6.9-73.5)$ & $27.8 \pm 11.9(8.5-75.0)$ & $28.9 \pm 11.1(6.9-75.0)$ \\
\hline Oesophageal varices reported, $n$ & 4 & 1 & 5 \\
\hline Platelet count < $75.0 \times 10^{9} / \mathrm{l}, n(\%)$ & $19(25.6)$ & $9(20.0)$ & $28(22.0)$ \\
\hline \multicolumn{4}{|l|}{ Fibrosis stage (METAVIR or FibroScan) } \\
\hline$<\mathrm{F} 3, n$ & 5 & 3 & 8 \\
\hline $\mathrm{F} 3, n$ & 3 & 5 & 8 \\
\hline F4 (cirrhosis), $n$ (\%) & $74(90.2)$ & $37(82.2)$ & $111(87.4)$ \\
\hline \multicolumn{4}{|l|}{ Liver function tests } \\
\hline Elevated baseline ALT, $n(\%)$ & $73(89.0)$ & $42(93.3)$ & $115(90.6)$ \\
\hline Elevated baseline GGT, n/available (\%) & $44 / 67(65.7)$ & $24 / 39(61.5)$ & $68 / 106(64.2)$ \\
\hline \multicolumn{4}{|l|}{ HCV subtype } \\
\hline $\mathrm{GT} 1 \mathrm{~b}, n(\%)$ & $74(90.2)$ & $43(95.6)$ & $117(92.1)$ \\
\hline GT1 non-1b, total, $n(\%)$ & $8(9.8)$ & $2(4.4)$ & $10(7.9)$ \\
\hline GT1a, $n$ & 2 & 2 & 4 \\
\hline $\mathrm{GT} 1 \mathrm{a}+1 \mathrm{~b}, n$ & 2 & 0 & 2 \\
\hline GT1, subtype untypable, $n$ & 4 & 0 & 4 \\
\hline \multicolumn{4}{|l|}{ HCV baseline viral load } \\
\hline HCV RNA, median (range), MIU/ml & $0.94(<0.1-19.2)$ & $1.27(<0.1-12.1)$ & $0.99(<0.1-19.2)$ \\
\hline HCV RNA viral load $\leqslant 0.8 \mathrm{MIU} / \mathrm{ml}, n(\%)$ & $37(45.1)$ & $17(37.8)$ & $54(42.5)$ \\
\hline HCV RNA viral load $>0.8-\leqslant 2 \mathrm{MIU} / \mathrm{ml}, n(\%)$ & $22(26.9)$ & $14(31.1)$ & $36(28.4)$ \\
\hline HCV RNA viral load > 2 MIU/ml, $n(\%)$ & $23(28.0)$ & $14(31.1)$ & $37(29.1)$ \\
\hline
\end{tabular}


Table 1. Cont.

\begin{tabular}{|c|c|c|c|}
\hline Parameter & Boceprevir & Telaprevir & Total \\
\hline \multicolumn{4}{|l|}{ Response to previous therapy } \\
\hline Non-response, $n(\%)$ & $47(57.3)$ & $17(37.8)$ & $64(50.4)$ \\
\hline Breakthrough, $n(\%)$ & 0 & $5(1.1)$ & $5(3.9)$ \\
\hline Relapse, $n(\%)$ & $21(25.6)$ & $12(26.7)$ & $33(26.0)$ \\
\hline Unknown/early termination, $n(\%)$ & $14(17.1)$ & $11(24.4)$ & $25(19.7)$ \\
\hline \multicolumn{4}{|l|}{ Relevant reported co-morbidities } \\
\hline Other liver diseases, $n$ & 3 & 1 & 4 \\
\hline HBV co-infection, $n$ & 0 & 0 & 0 \\
\hline HIV co-infection, $n$ & 0 & 2 & 2 \\
\hline Hypertension, $n(\%)$ & $34(41.5)$ & $20(44.4)$ & $54(42.5)$ \\
\hline Diabetes mellitus, $n(\%)$ & $23(28.0)$ & $7(15.6)$ & $30(23.6)$ \\
\hline Coronary artery disease, $n(\%)$ & 9 & 4 & $13(10.2)$ \\
\hline Thyroid disease, $n(\%)$ & 9 & 4 & $13(10.2)$ \\
\hline GERD, $n(\%)$ & 7 & 4 & $11(8.7)$ \\
\hline Depression, $n$ & 6 & 3 & $9(7.1)$ \\
\hline Cryoglobulinemia \pm vasculitis, $n(\%)$ & 6 & 1 & $7(5.5)$ \\
\hline End stage kidney disease (PD), $n$ & 1 & $2(1)$ & $3(1)$ \\
\hline
\end{tabular}

$n$ - number of patients, SEM - standard error of mean, HCV - hepatitis C virus, ALT - alanine aminotransferase, GGT - gamma-glutamyl transpeptidase, GT - genotype, RNA - ribonucleic acid, HBV - hepatitis B virus, HIV - human immunodeficiency virus, GERD - gastroesophageal reflux disease, PD - peritoneal dialysis

and GT1b subtype infected (92.15\%). Of note, co-morbidities were reported in $89 \%$ of patients.

\section{Efficacy}

Disposition of patients and key HCV RNA results are shown in Figure 1, while detailed virological outcomes for patients who reached the pre-defined time points are listed in Table 2.

By the EOT time point one patient died due to myocardial infarction, one did not attend this visit, while 125/127 reached undetectable or detectable with below the LLD HCV RNA (98.4\% in ITT analysis, $100.0 \%$ in mITT analysis). After reaching SVR12, an additional patient with non-subtypable GT1 infection died due to recurrent HCC and deterioration of liver functions. In ITT or mITT analysis, SVR12 (where HCV RNA tests were performed), SVR24 and combined SVR12/24 results were $81 / 83(97.6 \%)$ or $81 / 82$ (98.8\%), 74/77 (96.1\%) or 74/75 (98.7\%) and 103/105 (98.1\%) or $103 / 104(99.0 \%)$, respectively (Table 2$)$. All 10 non-GT1b patients have reached SVR12/24 results. Separate analysis of BOC versus TEL failure patients was considered senseless with one single viral failure in this cohort. Normalization of ALT was reported in 94/105 patients (89.5\%).

Virological failure was observed only in one patient, a 56-year-old male, with GT1b HCV infection and compensated liver cirrhosis, with advanced fibrosis on transient elastography (liver stiffness $39.7 \mathrm{kPa}$ ), treated previously with $\mathrm{BOC}$ triple therapy with an outcome of relapse. This obese patient (BMI $37.2 \mathrm{~kg} / \mathrm{m}^{2}$ ) with no other relevant co-morbidities received a relatively low dose of RBV (600 mg per day) due to grade 4 anaemia during previous BOC-based treatment. $\mathrm{He}$ was reportedly adherent to the therapy (HCV RNA was undetectable at the EOT time point). NS3A/4 baseline RASs were detected in this patient (Table 3 ). On relapse 12 weeks after 3DAA therapy, a sample for RAS re-testing was taken. However, due to technical reasons, this sample could not be analysed. This patient was subsequently treated with sofosbuvir/ledipasvir + ribavirin (800 mg per day) therapy for 24 weeks, and reached an SVR.

No specific adherence measures have been applied in this real-life data collection. However, the EOT results suggest excellent adherence to the therapy; only one patient did not attend the EOT visit (but attended later the $\mathrm{EOT}+24$ weeks visit).

\section{Safety}

Four (3.1\%) SAEs have been reported in this cohort. One patient with a past medical history of coronary artery disease died due to myocardial infarction during the second week of $3 \mathrm{DAA}+\mathrm{RBV}$ therapy. No 


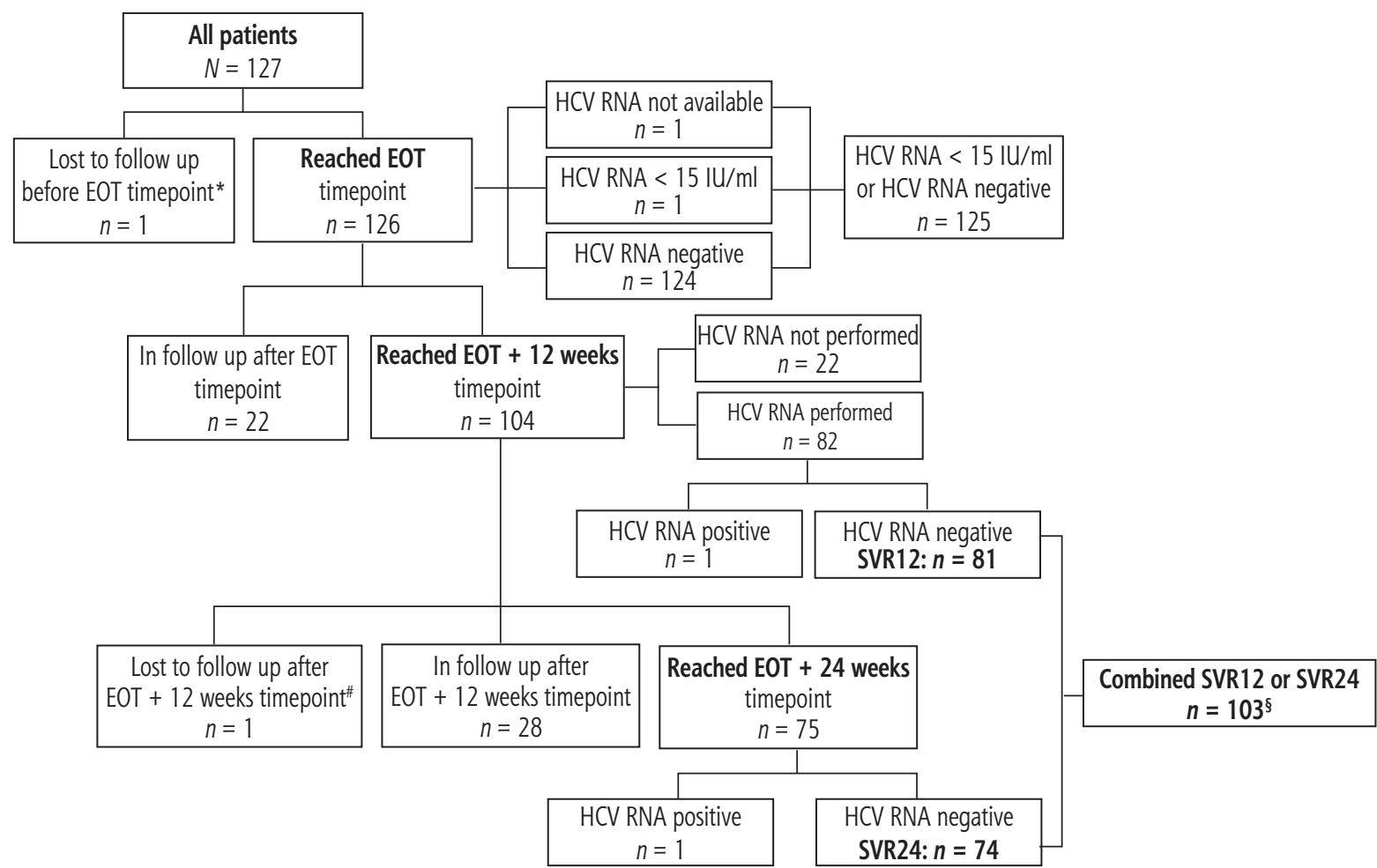

*One patient died due to myocardial infarction while on therapy; not included in modified ITT analysis.

\#One patient reached SVR12, but died due to recurrent hepatocellular carcinoma and deterioration of liver disease before EOT+24 weeks time point; not included in modified ITT SVR24 analysis.

$\$ 50$ patients had negative HCV RNA testing at both EOT+12 and EOT+24 time points; all other patients had HCV RNA testing only at one of these time points.

EOT - end of treatment, HCV - hepatitis C virus, ITT - intent to treat, $N$ - number of patients, RNA - ribonucleic acid, SVR - sustained virological response

Fig. 1. Disposition of patients and key HCV RNA results

Table 2. Virological outcomes for patients who reached the pre-defined time points

\begin{tabular}{|c|c|c|c|c|}
\hline Parameter & EOT & EOT+12 weeks & EOT + 24 weeks & $\begin{array}{c}\text { EOT }+12 \text { or EOT }+24 \\
\text { weeks combined }\end{array}$ \\
\hline Number of patients evaluated at the time point, $N$ & 127 & 83 & 77 & 105 \\
\hline In follow-up at the time point, $n$ & 0 & 22 & 50 & 22 \\
\hline Lost to follow-up, $n$ & $1 *$ & $1 *$ & $2 * \#$ & $1 *$ \\
\hline Missed visit, $n$ & 1 & $22^{\S}$ & 0 & 0 \\
\hline Patients with available HCV RNA data, $n$ & 125 & 82 & 75 & 104 \\
\hline HCV RNA target detected, quantifiable, $n$ & 0 & 1 & 1 & 1 \\
\hline HCV RNA target detected, below LLD, $n$ & 1 & 0 & 0 & 0 \\
\hline HCV RNA target not detected, $n / N(\%)$ & 124 & 81 & 74 & 103 \\
\hline Virological response rate, ITT, n/N (\%) & $125 / 127(98.4)$ & $81 / 83(97.6)$ & $74 / 77(96.1)$ & $103 / 105(98.1)$ \\
\hline Virological response rate, $\mathrm{mITT}, n / N(\%)$ & $125 / 125(100.0)$ & $81 / 82(98.8)$ & $74 / 75(98.7)$ & 103/104 (99.0) \\
\hline \multicolumn{5}{|c|}{$\begin{array}{l}\text { *One patient died due to myocardial infarction while on therapy; not included in modified ITT analysis. } \\
\text { \#One patient who reached SVR } 12 \text { died due to recurrent hepatocellular carcinoma and deterioration of liver disease before EOT+24 weeks time point; not included in modified ITT } \\
\text { SVR24 analysis. } \\
\text { §HCV RNA testing at EOT+12 weeks time point is not mandatory in Hungary. } \\
N \text { - total number of patients, } n \text { - number of patients, EOT - end of treatment, HCV - hepatitis C virus, RNA - ribonucleic acid, LLD - Iower limit of detection, ITT - intent to treat, } \\
\text { mITT - modified intent to treat, SVR - sustained virological response }\end{array}$} \\
\hline
\end{tabular}


Table 3. Resistance associated substitutions (RASs) detected for different non-structural proteins (NS) at baseline in patient with relapse

\begin{tabular}{lccc}
\hline Category of RAS & NS3A/4 & NS5A & NS5B (non-nucleotide) \\
\hline RAS(s) detected & A156A/T & Not tested & Not detected \\
\hline VAS - resistance associated substitution, NS - non-structural protein & & \\
\hline
\end{tabular}

relevant anaemia was observed during this short period of therapy. This SAE was considered as not related to the $3 \mathrm{DAA}+\mathrm{RBV}$ therapy by the treating physician. After reaching SVR12, one cirrhotic patient with a past medical history of cured HCC died due to recurrent HCC and deterioration of liver functions. Relation of this SAE to the therapy was considered as possible by the treating physician. One patient was hospitalized due to elevation of liver enzymes (LFTs) > 10× above the upper limit of normal. This SAE did not lead to therapy discontinuation or modification, and subsequently was resolved on continued $3 \mathrm{DAA}+\mathrm{RBV}$ therapy. A relation to the therapy was considered as likely by the treating physician. This patient has reached an SVR24. One patient developed pneumonia requiring hospitalization. The pneumonia was subsequently resolved on antibiotic therapy with no therapy discontinuation or modification. This SAE was considered as not related to the $3 \mathrm{DAA}+\mathrm{RBV}$ therapy by the treating physician. The patient has reached an SVR24.

AEs reported in more than one patient are shown in Table 4. Discontinuations, dose reductions, reported relevant on-treatment laboratory abnormalities by WHO grade and anaemia management measures are shown in Table 5. None of the reported AEs or laboratory abnormalities led to therapy discontinuation, and reportedly all of them resolved without sequelae during or after the therapy. No grade 3 or 4 anaemia has been reported.

Table 4. Adverse events reported in more than one patient

\begin{tabular}{lcc}
\hline Category & $\begin{array}{c}\text { Reported } \\
\text { incidence } \\
(\boldsymbol{n}=109)\end{array}$ & $\begin{array}{c}\text { Projected } \\
\text { incidence* } \\
(\boldsymbol{n}=127)\end{array}$ \\
\hline Weakness, $n(\%)$ & $8(7.3)$ & $(6.3)$ \\
\hline Dry skin or itching, $n(\%)$ & $6(5.5)$ & $(4.7)$ \\
\hline Dry mouth or itching tongue, $n(\%)$ & $4(3.7)$ & $(3.1)$ \\
\hline Cough, $n(\%)$ & $3(2.8)$ & $(2.4)$ \\
\hline Nycturia, $n(\%)$ & $3(2.8)$ & $(2.4)$ \\
\hline Nausea, $n(\%)$ & $2(1.8)$ & $(1.6)$ \\
\hline Skin rash, $n(\%$ & $2(1.8)$ & $(1.6)$ \\
\hline Dizziness, $n(\%)$ & $2(1.8)$ & $(1.6)$
\end{tabular}

*Projected incidence: assumption of no adverse event in the patient if not reported by the treating physician.
Grade 1 anaemia was reported in 24 patients, but only 9 required RBV dose reduction (by 200-400 mg).

\section{Discussion}

According to our knowledge, this is the largest dataset on the efficacy and safety of 3DAA+RBV combination therapy in HCV infected patients who failed previous $\mathrm{BOC} / \mathrm{TEL}$ based triple therapy. The $3 \mathrm{DAA}+\mathrm{RBV}$ combination is not registered for the treatment of $\mathrm{HCV}$ infected patients who failed previous BOC/TEL containing triple therapies, and is not recommended for this patient category by international professional guidelines [6, 7]. However, with no other therapeutic option available in Hungary at the time of initiation of

Table 5. Discontinuations, dose reductions, reported relevant on-treatment laboratory abnormalities by WHO grade, anaemia management

\begin{tabular}{|c|c|c|}
\hline Category & $\begin{array}{l}\text { Reported } \\
\text { incidence } \\
(n=109)\end{array}$ & $\begin{array}{l}\text { Projected } \\
\text { incidence* } \\
(n=127)\end{array}$ \\
\hline \multicolumn{3}{|l|}{ Therapy discontinuation/dose modification } \\
\hline Discontinuation of any of the drugs, $n(\%)$ & $1(0.9)^{\&}$ & $(0.8)$ \\
\hline Ribavirin dose reduction, $n(\%)$ & $9(8.3)$ & $(7.1)$ \\
\hline \multicolumn{3}{|l|}{ Laboratory abnormalities } \\
\hline $\begin{array}{l}\text { Transaminase elevation by grade }>1 \\
\text { from baseline, } n(\%)\end{array}$ & $1(0.9)$ & $(0.8)$ \\
\hline \multicolumn{3}{|l|}{ Hyperbilirubinema } \\
\hline Grade $1, n(\%)$ & $3(2.8)$ & $(2.4)$ \\
\hline Grade $>1, n$ & 0 & 0 \\
\hline \multicolumn{3}{|l|}{ Anemia } \\
\hline Grade $1, n(\%)$ & $24(22.0)$ & $(18.9)$ \\
\hline Grade $2, n(\%)$ & $2(1.8)$ & $(1.6)$ \\
\hline Grade $>2, n$ & 0 & 0 \\
\hline Neutropenia, any grade, $n$ & 0 & 0 \\
\hline $\begin{array}{l}\text { Thrombocytopenia, progressed } \\
\text { on treatment }{ }^{\#}, n\end{array}$ & 0 & 0 \\
\hline Transfusion/erythropoietin use, $n$ & 0 & 0 \\
\hline
\end{tabular}

*Projected incidence: assumption of no discontinuation/dose reduction/laboratory abnormality in patient if not reported by the treating physician.

\&This patient died due to myocardial infarction in the second week of therapy.

\#Baseline grade $\geqslant 2$ thrombocytopenia improved by at least one WHO grade during or after therapy in $5 / 28$ patients (17.9\%). 
this programme, use of this combination has been approved in the Hungarian National HCV guideline for previous BOC/TEL-failure patients with G1b infection by consensus of treating physicians [8].

In an ITT analysis as high as $98.1 \%$ (99.0\% in mITT analysis) combined SVR12 and/or SVR24 has been observed in this dominantly HCV GT1b infected population, despite a $87.4 \%$ frequency of liver cirrhosis, when $3 \mathrm{DAA}+\mathrm{RBV}$ therapy was commenced at least one year apart from the previous PI therapy.

Based on our data, this combination seems just as effective and safe in patients after PI failure as reported in those with no previous therapy or in those who failed previous PegIFN+RBV dual therapy. The efficacy outcomes are also in line with those achieved using any other registered therapies after PI failure, including combinations of daclatasvir+sofosbuvir $\pm \mathrm{RBV}$, grazoprevir/elbasvir, ledipasvir/sofosbuvir+RBV or velpatasvir/sofosbuvir (95\% to $100 \%$ in different studies) [10-13].

Only one out of 105 patients who reached the EOT +12 weeks time point experienced virological failure (relapse). NS3A/4 RASs could be detected prior to 3DAA therapy, and a relatively low dose $(5.5 \mathrm{mg} / \mathrm{kg})$ of ribavirin was taken by this patient. This patient could be rescued and reached an SVR subsequently with sofosbuvir/ledipasvir + ribavirin therapy, the other IFN-free combination available in our country.

Reported SAEs, AEs and laboratory abnormalities matched the frequencies of such events in patients treated with RBV containing 3DAA regimens in registration trials $[6,7]$. Although the dose of RBV was reduced in a proportion of patients (8.3\%), no transfusion, no erythropoietin use and no therapy discontinuation have been reported due to anaemia.

Similarly positive real life experiences have been demonstrated in PI-failure HCV GT1 infected patients when treated with $3 \mathrm{DAA} \pm \mathrm{RBV}$ therapy, with SVR rates of $46 / 48(96 \%)$ and $16 / 16(100 \%)$ in the German hepatitis $\mathrm{C}$ registry and in the Polish AMBER cohort $[14,15]$.

\section{Strengths and limitations}

Viral load, HCV genotype and fibrosis stage data as well as previous and current treatment allocations and assignments data are reliably registered in the Hungarian Hepatitis Registry system (mandatory for treatments). However, all other data were retrospectively reported by the treating physicians, and occasionally they might not be complete and/or adequate. In particular, data on co-morbidities, SAEs, AEs, laboratory abnormalities and/or RBV dose modifications might not be completely reliable. Furthermore, this is an interim analysis with SVR12 or SVR24 data available only for a proportion of patients who started therapy. In addition, there is no control/parallel group in this retrospective cohort for a direct comparison to either different patient populations or different therapy regimens. With no comparative RBV-free arm in the cohort, the hypothesized benefit of adding RBV to the 3DAA combination in this PI-failure patient population (with several additional negative factors: $87.4 \%$ cirrhotics, co-morbidities in $89 \%$ of patients) remains unclear.

In conclusion, when administered at least one year apart, the 3DAA+RBV combination was found effective and safe in HCV GT1 infected patients who failed previous BOC/TEL-based therapies in this cohort, regardless of presence or absence of liver cirrhosis. Although these findings might not be of pivotal importance in many countries with unlimited access to effective IFN-free combinations, they might still be of particular interest in settings where other therapies for such patients are not available or not affordable.

\section{Acknowledgements}

The authors thank the participating patients and their family members and the contributing physicians for their support.

Contributors (affiliation, number of patients). Abonyi M (Semmelweis University, Budapest, $n=5$ ), Bali I (Tolna Megyei Önkormányzat Balassa János Hospital, Szekszárd, $n=2$ ), Bányai T (Békés Megyei Képviselőtestület Pándy Kálmán Hospital, Gyula, $n=3$ ), Döbrönte Z (Markusovszky Uinersity Teaching Hospital, Sombathely, $n=1$ ), Enyedi J (Heves Megyei Önkormányzat Markhot Ferenc Kórház-Rendelőintézete, Eger, $n=2$ ), Fried K (Fővárosi Önkormányzat Egyesített Szent István and Szent László Hospital, Budapest, $n=1$ ), Gasztonyi B (Zala County Hospital, Zalaegerszeg, $n=2$ ), Gerlei Zs (Semmelweis University, Budapest, $n=1$ ), Gervain J (Fejér Megyei Szent György University Teaching Hospital, Székesfehérvár, $n=3$ ), Haragh A (Somogy County Kaposi Mór Teaching Hospital, Kaposvár, $n=1$ ), Horváth G (Főváros Önkormányzat Szent János and Észak-budai Egyesített Hospitals and Hepatology Centre of Buda, Budapest, $n=9$ ), Hunyady B (Somogy County Kaposi Mór Teaching Hospital, Kaposvár and University of Pécs, Pécs, $n=2$ ), Jancsik V (Kenézy Gyula Hospital and Outpatient Clinic, Debrecen, $n=9$ ), Lengyel G (Semmelweis University, Budapest, $n=4$ ), Lombay B (Borsod-Abaúj-Zemplén Megyei Kórház és Egyetemi Oktató Kórház, Miskolc, $n=1$ ), Makara M (Fövárosi Önkormányzat Egyesített Szent István and Szent Lász- 
ló Hospital, Budapest, $n=7$ ), Makkai E (Magyar Imre Hospital, Ajka, $n=6$ ), Martyin T (Békés County Pándy Kálmán Hospital, Gyula, $n=2$ ), Müller Zs (Fejér County Szent György University Teaching Hospital, Székesfehérvár, $n=3$ ), Nemesesánszky E (Fővárosi Önkormányzat Szent János Kórház és Rendelőintézet, Budapest, $n=1$ ), Palatka K (University of Debrecen, Debrecen, $n=2$ ), Pár A (University of Pécs, Pécs, $n=2$ ), Pár G (University of Pécs, Pécs, $n=1$ ), Pusztay M (Fővárosi Önkormányzat Szent János Kórház és Rendelőintézet, Budapest, $n=3$ ), Reé J (Fővárosi Önkormányzat Egyesített Szent István and Szent László Hospital, Budapest, $n=2$ ), Ribiczey $\mathrm{P}$ (Zala Coutny Hospital, Zalaegerszeg, $n=6$ ), Schneider F (Markusovszky University Teaching Hospital, Szombathely, $n=5$ ), Szalay F (Semmelweis University, Budapest, $n=1$ ), Szinku Zs (Somogy County Kaposi Mór Teaching Hospital, Kaposvár, $n=3$ ), Szlávik J (Fővárosi Önkormányzat Egyesített Szent István and Szent László Hospital, Budapest, $n=2$ ), Tolvaj Gy (Magyar Honvédség Medical Centre, Budapest, $n=2$ ), Tornai I (University of Debrecen, Debrecen, $n=7$ ), Tusnádi A (Jász-NagykunSzolnok County Hetényi Géza Hospital, Szolnok, $n=5$ ), Weisz Gy (Kenézy Gyula Hospital and Outpatient Clinic, Debrecen, $n=1$ ), Werling K (Semmelweis University, Budapest, $n=4)$.

\section{Previous publication}

Preliminary data in this cohort have been presented in a poster at the International Liver Congress, 2016: Hunyady B, Abonyi M, Gervain J, et al. Ombitasvir/ paritaprevir/ritonavir + dasabuvir + ribavirin (3DAA $+\mathrm{RBV})$ treatment of hepatitis $\mathrm{C}(\mathrm{HCV})$ genotype 1 (GT1) infected patients after failure to previous first generation protease inhibitor (PI) therapy. Interim analysis. ILC 2016. Abstract SAT-120. J Hepatol 2016; 64 (Suppl 2): S750.

\section{Disclosure}

Authors report no conflict of interest.

\section{References}

1. European Medicines Agency (EMA). Victrelis. Summary of product characteristics. Updated: 23/06/2016. Available from: http:// www.ema.europa.eu/docs/en_GB/document_library/EPAR_-Product_Information/human/002332/WC500109786.pdf

2. European Medicines Agency (EMA). Incivo. Summary of product characteristics. Updated: 06/10/2016. Available from: http://www. ema.europa.eu/docs/en_GB/document_library/EPAR_-_Product_Information/human/002313/WC500115529.pdf

3. Sullivan JC, De Meyer S, Bartels DJ, et al. Evolution of treatment-emergent resistant variants in telaprevir phase 3 clinical trials. Clin Infect Dis 2013; 57: 221-229.
4. Bartels DJ, Sullivan JC, Zhang EZ, et al. Hepatitis C virus variants with decreased sensitivity to direct-acting antivirals (DAAs) were rarely observed in DAA-naive patients prior to treatment. J Virol 2013; 87: 1544-1553.

5. Howe AY, Long J, Nickle D, et al. Long-term follow-up of patients receiving boceprevir for treatment of chronic hepatitis C. Antiviral Res 2015; 113: 71-78.

6. European Medicines Agency (EMA). Viekirax. Summary of product characteristics. Updated: 25/08/2016. Available from: http:// www.ema.europa.eu/ema/index.jsp?curl=pages/medicines/human/medicines/003839/human_med_001838.jsp\&mid=WC0b01ac058001d124

7. European Medicines Agency (EMA). Exviera. Summary of product characteristics. Updated: 24/05/2016. Available from: http:// www.ema.europa.eu/docs/en_GB/document_library/EPAR_-Product_Information/human/003837/WC500182233.pdf

8. Hunyady B, Gerlei Z, Gervain J, et al. Diagnosis, treatment, and follow-up of hepatitis $C$ virus related liver disease. Hungarian national consensus guideline. Orv Hetil 2015; 156 (Suppl 1): 3-23 [In Hungarian].

9. Dietz J, Susser S, Vermehren J, et al. Patterns of resistance-associated substitutions in patients with chronic HCV infection following treatment with direct-acting antivirals. Gastroenterology 2018; 154: 976-988.

10. European Medicines Agency (EMA). Daklinza. Summary of product characteristics. Updated: 19/10/2016. Available from: http:// www.ema.europa.eu/docs/en_GB/document_library/EPAR_-_ Product_Information/human/003768/WC500172848.pdf

11. European Medicines Agency (EMA). Harvoni. Summary of product characteristics. Updated: 28/07/2016. Available from: http:// www.ema.europa.eu/docs/en_GB/document_library/EPAR_-_ Product_Information/human/003850/WC500177995.pdf

12. European Medicines Agency (EMA). Epclusa. Summary of product characteristics. Published: 28/07/2016. Available from: http:// www.ema.europa.eu/docs/en_GB/document_library/EPAR_Product_Information/human/004210/WC500211151.pdf

13. European Medicines Agency (EMA). Zepatier. Summary of product characteristics. Published: 28/07/2016. Available from: http:// www.ema.europa.eu/docs/en_GB/document_library/EPAR_Product_Information/human/004126/WC500211235.pdf

14. Hinrichsen $\mathrm{H}$, Wedemeyer $\mathrm{H}$, Christensen $\mathrm{S}$, et al. Real-world safety and effectiveness of ombitasvir/paritaprevir/ $\mathrm{r}$ with dasabuvir and/or ribavirin in the German hepatitis C registry. ILC 2016. Abstract GS07. J Hepatol 2016; 64 (Suppl 2): S159.

15. Flisiak R, Janczewska E, Wawrzynowicz-Syczewska M, et al. Realworld effectiveness and safety of ombitasvir/paritaprevir/ritonavir \pm dasabuvir \pm ribavirin in hepatitis C: AMBER study. Aliment Pharmacol Ther 2016; 44: 946-956. 